\section{DESAIN LEMBAR AKTIVITAS SISWA (LAS) UNTUK MENINGKATKAN KEMAMPUAN SISWA MEMAHAMI KONSEP PEMBAGIAN PECAHAN DI SD NEGERI 095 I 73 SIHEMUN}

Firman Pangaribuan', Juli Antasari Br. Sinaga $^{2}$, Herman ${ }^{3}$

1,2,3 Universitas HKBP Nommensen

*Corresponding author

Email: julisinaga@uhn.ac.id

\begin{abstract}
The concept of dividing fractions is still a difficult concept for most of the students. Many elementary and junior high school students have not been able to write the fraction division formula correctly $\frac{a}{b}: \frac{c}{d}=\frac{a}{b} \times \frac{d}{c}$. Students who can write the fraction division formula correctly cannot explain the meaning of the formula. Students can solve the problem of dividing the fraction stated in the story problem using the fraction division formula but do not understand why the formula applies. Teaching the concept of dividing fractions does not require students to learn meaningfully, only armed with formulas, theories and examples of question. Learning resources (student handbooks) do not fully facilitate students to understand the concept of dividing fractions. This service activity was carried out on August 10, 2020, at SD Negeri 095 I 73 Sihemun Kec. Dolok Pardamean Kab. Simalungun. The target of this activity is the fifth-grade elementary school students, amounting to 20 people. This activity aims to overcome students' difficulties in understanding the concept of dividing fractions and provide learning motivation for students. This service activity is carried out by lecturers of the FKIP Mathematics Education Study Program, HKBP Nommensen University as a planner, implementer, and teacher/tutor. This activity also involved two selected students who participated in this activity. The discussion method is prioritized in the learning process to solve the various problems listed in the LAS that the lecturer has designed. This service activity was carried out well and effectively in solving student difficulties in understanding dividing fractions. This is reflected in the indicators of student success in achieving complete scores above the KKM by $90 \%$ and $100 \%$ of students giving a positive response to the learning process and $85 \%$ of students saying they were happy with learning using LAS media designed by a team of lecturers.
\end{abstract}

Keywords: Fraction Division Concept; Student Activity Sheet Design; Concept Understanding

\footnotetext{
Abstrak

Konsep pembagian pecahan masih merupakan konsep yang sulit bagi sebagian besar siswa. Banyak siswa SD maupun SMP belum dapat menulis dengan benar rumus pembagian pecahan $\frac{a}{b}: \frac{c}{d}=\frac{a}{b} \times \frac{d}{c}$. Siswa yang dapat menulis dengan benar rumus pembagian pecahan, tidak dapat menjelaskan mengapa demikian. Siswa dapat menyelesaikan masalah pembagian pecahan yang dinyatakan dalam soal cerita dengan menggunakan rumus pembagian pecahan, tetapi tidak memahami mengapa rumus itu berlaku. Guru dalam mengajarkan konsep pembagian pecahan tidak menuntut siswa kepada pembelajaran bermakna, hanya berbekal rumus, teori dan contoh soal yang diajarkan kepada siswa. Sumber belajar (buku pegangan siswa) belum seutuhnya memfasilitasi siswa untuk memahami konsep pembagian pecahan. Kegiatan pengabdian ini dilakukan pada tanggal 10 Agustus 2020 di Sekolah SD Negeri 095173 Sihemun Kec. Dolok Pardamean Kab. Simalungun. Target kegiatan ini adalah siswa kelas V SD yang berjumlah 20 orang. Kegiatan ini bertujuan untuk mengatasi kesulitan siswa dalam memahami konsep pembagian pecahan dan memberikan motivasi belajar bagi siswa. Kegiatan pengabdian ini dilakukan oleh dosen-dosen Program Studi Pendidikan Matematika FKIP Universitas HKBP Nommensen sebagai perencana, pelaksana dan sekaligus sebagai pengajar/ tutor. Kegiatan ini juga melibatkan 2 orang mahasiswa pilihan yang turut berpartisipasi dalam kegiatan ini. Metode diskusi lebih diutamakan dalam proses pembelajaran untuk menyelesaikan berbagai persoalan yang tertera pada LAS yang telah di desain oleh dosen. Kegiatan pengabdian ini terlaksana dengan baik dan efektif dalam menuntaskan kesulitan siswa memahami konsep pembagian pecahan. Hal ini tercermin dari indikator keberhasilan siswa mencapai nilai tuntas diatas KKM sebesar $90 \%$ dan 100\% siswa memberikan respon positif atas proses pembelajaran dan $85 \%$ siswa menyatakan senang atas pembelajaran menggunakan media LAS yang didesain oleh tim dosen.
} 
Jubaedah : Jurnal Pengabdian dan Edukasi Sekolah

(Indonesian Journal of Community Services and School Education)

http://jubaedah.Ippmbinabangsa.id/index.php/home

Kata Kunci: Konsep Pembagian Pecahan; Desain Lembar Aktivitas Siswa; Pemahaman Konsep

Received: April 23, 202 I / Accepted: April 27, 202 I / Published Online: April 27, 202 I 
Desain Lembar Aktivitas Siswa (LAS) Untuk Meningkatkan Kemampuan Siswa Memahami Konsep Pembagian

Pecahan SD Negeri 095173 Sihemun

Firman Pangaribuan, Juli Antasari Br. Sinaga, Herman

Volume 01, No. 01, April 2021 hal. 69-76

DOI Artikel : 10.46306/jub.v1i1.15

\section{PENDAHULUAN}

Matematika sebagai ilmu terstruktur yang memiliki keterkaitan antara konsep yang satu dengan konsep lainnya menjadikan matematika sebagai bidang ilmu yang sulit dipahami oleh sebagian besar siswa. Oleh karena itu peguatan konsep matematika harus dilakukan sejak dini. Friantini, dkk (2020:277) menyatakan bahwa penguatan konsep matematika sejak dini diterapkan semakin baik sehingga konsep matematika dapat benar-benar terserap dan dipahami semaksimal mungkin. Konsep pembagian pecahan adalah konsep yang juga memiliki banyak keterkaitan bukan saja dengan konsep matematika itu sendiri, melainkan berkaitan juga pada bidang ilmu lainnya yang membutuhkan konsep pembagian pecahan untuk menyelesaikan berbagai persoalan.

Pembagian pecahan merupakan salah satu konsep yang sulit dipahami bagi sebagian besar siswa dan guru. Pembagian pecahan merupakan topik yang paling sulit dalam matematika dasar bagi siswa dan juga bagi guru, karena pembagian adalah operasi yang paling kompleks dari 4 operasi dasar matematika dan pecahan juga merupakan bilangan yang paling kompleks dalam aritmetika (Ervin, 2017).

Banyak siswa SD maupun SMP belum dapat menulis dengan benar rumus pembagian pecahan $\frac{a}{b}: \frac{c}{d}=$ $\frac{a}{b} \times \frac{d}{c}$. Mereka yang dapat menulis dengan benar rumus pembagian pecahan itu tidak dapat menjelaskan mengapa demikian. Beberapa siswa SMP dapat menulis dengan benar rumus pembagian pecahan yaitu; $\frac{a}{b}: \frac{c}{d}=\frac{a}{b} \times \frac{d}{c}$ atau $\frac{a}{b}: \frac{c}{d}=\frac{a d}{b d}: \frac{b c}{b d}=a d: b c$ atau $\frac{a}{b}: \frac{c}{d}=\frac{a: c}{b: d}$. Siswa-siswa tersebut dapat menyelesaikan masalah pembagian pecahan yang dinyatakan dalam soal cerita dengan menggunakan rumus pembagian pecahan, tetapi tidak memahami mengapa rumus itu berlaku (Pangaribuan, 20I6).

Hambatan yang dialami siswa belajar pembagian pecahan tidak sejalan dengan tujuan belajar matematika khususnya pembagian pecahan. Menurut Kurikulum 2006, standar kompetensi tentang materi pecahan diharapkan dicapai siswa mulai kelas III SD. Siswa kelas V SD diharapkan dapat memecahkan masalah yang menyangkut operasi pembagian pecahan. Sejalan dengan itu, Kurikulum 2013 juga menyatakan bahwa siswa dapat melakukan pembagian pecahan dengan pendekatan ilmiah. Berdasarkan dua rujukan di atas berarti siswa tidak menerima langsung rumus pembagian pecahan, dan siswa membangun pemahaman pembagian pecahan itu dengan bantuan lingkungan maupun pengetahuan awal siswa. Dalam membangun pemahaman konsep siswa dibutuhkan media pembelajaran. Sebagaimana yang dinyatakan Hanum (Nizaruddin, dkk, 2020: 99) bahwa media pembelajaran yang dikemas dengan baik akan sangat efisien untuk mendukung tercapainya tujuan pembelajaran.

Kesulitan dalam menyelesaikan berbagai persoalan pembagian pecahan juga dialami oleh siswa kelas V SD Negeri Sihemun. Berdasarkan hasil observasi dan wawancara yang dilakukan oleh tim pengabdian kepada masyarakat (dosen dan mahasiswa) diperoleh informasi bahwa sebagian besar siswa dalam proses menyelesaikan operasi hitung bilangan pecahan (khususnya pembagian pecahan) masih banyak siswa yang berpatokan kepada rumus $\frac{a}{b}: \frac{c}{d}=\frac{a}{b} \times \frac{d}{c}$ dan hampir semua siswa tidak mampu menjelaskan secara nalar 
Desain Lembar Aktivitas Siswa (LAS) Untuk Meningkatkan Kemampuan Siswa Memahami Konsep Pembagian

Pecahan SD Negeri 095173 Sihemun

Firman Pangaribuan, Juli Antasari Br. Sinaga, Herman

Volume 01, No. 01, April 2021 hal. 69-76

DOI Artikel : 10.46306/jub.v1i1.15

atas jawabannya. Guru dalam mengajarkan konsep pembagian pecahan tidak menuntut siswa kepada pembelajaran bermakna, hanya berbekal rumus, teori dan contoh soal yang diajarkan kepada siswa. Sumber belajar (buku pegangan siswa) belum seutuhnya memfasilitasi siswa untuk memahami konsep pembagian pecahan. Berdasarkan fenomena tersebut sangat dibutuhkan adanya media seperti lembar aktivitas siswa (LAS) dengan menggunakan konteks situasi yang akrab kepada siswa, dalam hal ini menggunakan konteks jajanan martabak. LAS dengan konteks martabak ini diyakini akan dapat mendukung peningkatan pemahaman siswa pada materi pembagian pecahan secara khusus pembagian bilangan bulat dengan pecahan.

\section{METODE PENGABDIAN}

Kegiatan pengabdian ini dilakukan pada tanggal 10 Agustus 2020 di Sekolah SD Negeri 095173 Sihemun Kec. Dolok Pardamean Kab. Simalungun Propinsi Sumatera Utara. Target kegiatan ini adalah siswa kelas V SD yang berjumlah 20 orang, kegiatan ini berjalan dengan baik dan siswa terlihat begitu antusias mengikuti proses pembelajaran yang berlangsung di ruangan kelas. Kegiatan pengabdian ini dilakukan oleh dosen-dosen Program Studi Pendidikan Matematika FKIP Universitas HKBP Nommensen sebagai perencana, pelaksana dan sekaligus sebagai pengajar/ tutor. Kegiatan ini juga melibatkan 2 orang mahasiswa pilihan yang turut berpartisipasi dalam kegiatan ini. Metode diskusi lebih diutamakan dalam proses pembelajaran untuk menyelesaikan berbagai persoalan yang tertera pada LAS yang telah di desain oleh dosen. LAS yang didesain terdiri atas 5 tahap. Pertama LAS I bertujuan untuk mengingatkan kembali makna pecahan, LAS 2 untuk memahami pembagian dengan menggunakan konteks gambar, LAS 3 untuk memahami pembagian dengan konteks verbal (tanpa gambar), LAS 4 memahami pembagian dalam konteks matematika, dan terakhir memahami pembagian bilangan secara symbol matematika. Kenyamanan dalam pembelajaran juga penting diperhatikan untuk memperoleh berbagai alasan/respon siswa terkait jawaban yang ia temukan. Teknis kegiatan ini dilakukan dengan mengikuti jadwal yang telah direncanakan sebelumnya.

\section{PELAKSANAAN DAN PEMBAHASAN}

Tahapan dalam melaksanakan kegiatan pengabdian ini, terdiri dari:

\section{I) Tahap Perencanaan.}

Dalam tahap ini, perencanaan diawali dengan melakukan rapat dosen di Program Studi Pendidikan Matematika FKIP Universitas HKBP Nommensen dengan materi rapat adalah penentuan sekolah yang dituju sebagai tempat pengabdian, jenis kegiatan yang akan dilaksanakan, dan tanggal pelaksanaan. Penentuan sekolah diutamakan adalah sekolah yang berada didaerah terpencil dan masih membutuhkan pendampingan terkait masalah yang dihadapi oleh siswa atau guru. Berdasarkan informasi dari mahasiswa yang melaksanakan program PKM (program ini adalah agenda tahunan di FKIP Universitas HKBP Nommensen), sekolah SD Negeri 095173 Sihemun Kec. Dolok Pardamean Kab. Simalungun adalah sekolah terpencil dan masih membutuhkan pendampingan dalam peningkatan kemampuan pemahaman 
Desain Lembar Aktivitas Siswa (LAS) Untuk Meningkatkan Kemampuan Siswa Memahami Konsep Pembagian

Pecahan SD Negeri 095173 Sihemun

Firman Pangaribuan, Juli Antasari Br. Sinaga, Herman

Volume 01, No. 01, April 2021 hal. 69-76

DOI Artikel : 10.46306/jub.v1i1.15

konsep matematika. Tim Dosen dan mahasiswa melakukan kegiatan observasi juga wawancara terhadap guru dan siswa terkait konsep matematika yang sulit dipahami. Hasil observasi dan wawancara mengarahkan tim dosen untuk melakukan kegiatan pemberian bimbingan belajar konsep pembagian pecahan di kelas V SD. Setelah ditentukan materi maka tim dosen mempersiapkan desain LAS yang dirancang untuk membangun daya nalar siswa atas berbagai persoalan yang tersedia di LAS tersebut.

\section{2) Tahap Pelaksanaan.}

Kegiatan ini dilaksanakan pada tanggal 10 Agustus 2020. Pada tahap ini yang dikerjakan adalah pemberian bimbingan/ tutor kepada siswa kelas V SD terkait konsep pembagian pecahan dengan menggunakan media LAS sebagai penuntun siswa dalam menemukan konsep pembagian pecahan. Proses pembelajaran ditekankan kepada metode diskusi untuk dapat merangsang keinginan bertanya baik dengan teman atau dosen sebagai tutor, dan meningkatkan daya nalar, kreativitas dan berpikir kritis siswa melalui berbagai pertanyaan yang tertera pada LAS. Suasana belajar juga dibuat senyaman mungkin untuk membuat siswa tampil berani dalam mengemukakan pendapatnya dan memberi respon akan pendapat yang berbeda dengan temannya. Kegiatan ini berjalan dengan baik dan siswa yang menjadi target dalam kegiatan ini sangat antusias mengikuti pembelajaran, siswa bebas berkreasi dalam mengeluarkan ide, dan memberikan alasan-alasan logis atas jawaban yang diperolehnya.

\section{3) Tahap Evaluasi.}

Tahap ini merupakan bagian penting dari serangkaian kegiatan, dengan melakukan evaluasi akan didapat informasi mengenai kemajuan ketuntasan siswa dalam memahami konsep pembagian pecahan. Menurut Stufflebeam (Fitriani dkk, 2020:283) evaluasi merupakan proses untuk menggambarkan, memperoleh hingga menyajikan informasi yang berguna agar dapat merumuskan alternatif keputusan. Evaluasi dilakukan dengan memberikan tes pemahaman konsep pembagian pecahan kepada siswa yang terdiri atas 10 butir soal, dan soal tersebut telah disesuaikan dengan kompetensi dasar, indikator pemahaman konsep dan telah diuji kevalidannya. Saat tes berlangsung siswa bekerja sendiri, mengerahkan semua potensi dalam mengkritisi dan mencari solusi atas berbagai persoalan yang diberikan. Tim pendamping juga guru memberikan motivasi untuk memacu semangat dan percaya diri siswa dalam menyelesaikan tes tersebut. Berdasarkan hasil tes diperoleh $90 \%$ siswa atau sebanyak 18 orang siswa memperoleh nilai tuntas yakni nilai di atas 68. Berdasarkan hasil ini, dapat dikatakan bahwa kegiatan ini terlaksana dengan efektif dan memberikan hasil yang memuaskan.

Kegiatan ini membawa dampak positif bagi siswa, motivasi belajar siswa dalam mempelajari konsep matematika semakin tinggi. Ketakutan dan kejenuhan siswa dalam belajar matematika tidak lagi menjadi penghalang untuk penyampaian konsep-konsep matematika. Siswa merasa senang dan memberikan respon positif terhadap pembelajaran yang telah berlangsung. Berdasarkan pemberian umpan balik melalui angket diperoleh bahwa 100\% siswa memberikan respon positif akan pembelajaran dan dalam 
Desain Lembar Aktivitas Siswa (LAS) Untuk Meningkatkan Kemampuan Siswa Memahami Konsep Pembagian Pecahan SD Negeri 095173 Sihemun

Firman Pangaribuan, Juli Antasari Br. Sinaga, Herman

Volume 01, No. 01, April 2021 hal. 69-76

DOI Artikel : 10.46306/jub.v1i1.15

kolom komentar $85 \%$ siswa menyenangi proses pembelajaran melalui media LAS yang didesain khusus oleh tim dosen. Hasil ini membuat guru termotivasi untuk meningkatkan cara mengajarnya, dan tertarik untuk mendesain LAS yang dapat meningkatkan pemahaman siswa atas konsep matematika yang dipelajari. Sangat diharapkan kegiatan seperti ini dapat terus berjalan, pihak sekolah dan guru sepakat untuk terus melakukan kerjasama dengan para dosen untuk menuntaskan berbagai kesulitan yang dialami siswa dalam mempelajari konsep-konsep matematika. Berikut beberapa dokumentasi dari kegiatan pengabdian ini:

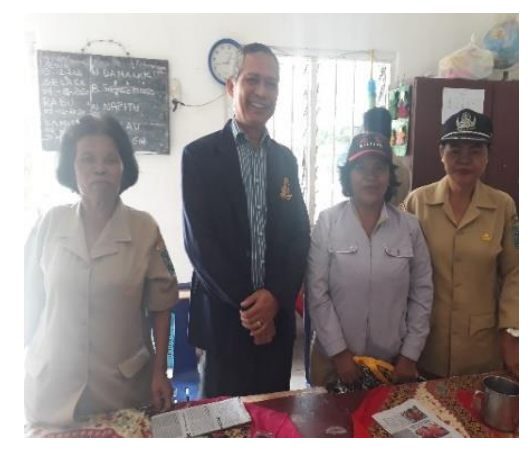

Gambar I. Tim Pengabdian (Dr. Firman Pangaribuan, M.Pd.) selaku pembicara bersama guru-guru bidang studi Matematika Sekolah SD Negeri 095 I 73 Sihemun Kec. Dolok Pardamean Kab. Simalungun

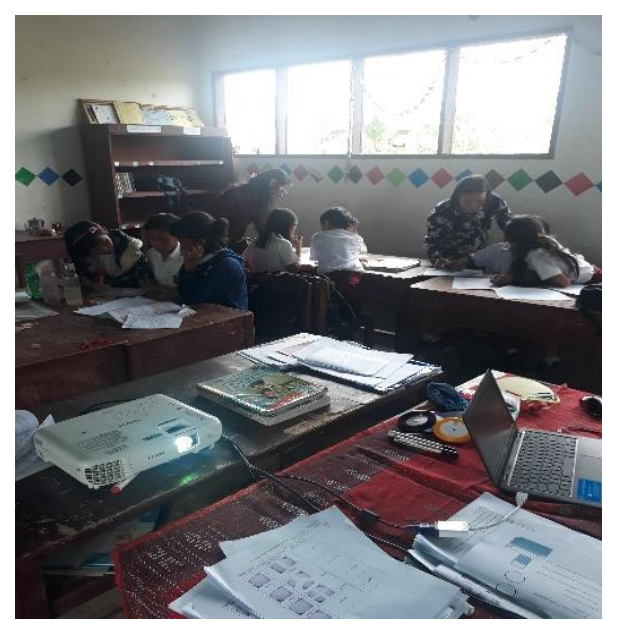

Gambar 2. Pendampingan Pembelajaran Konsep Pembagian Pecahan Menggunakan LAS I dan LAS 2 (Tim Pengabdian oleh Ibu Juli Antasari Sinaga, S.Pd., M.Pd.) 
Desain Lembar Aktivitas Siswa (LAS) Untuk Meningkatkan Kemampuan Siswa Memahami Konsep Pembagian Pecahan SD Negeri 095173 Sihemun

Firman Pangaribuan, Juli Antasari Br. Sinaga, Herman

Volume 01, No. 01, April 2021 hal. 69-76

DOI Artikel : 10.46306/jub.v1i1.15

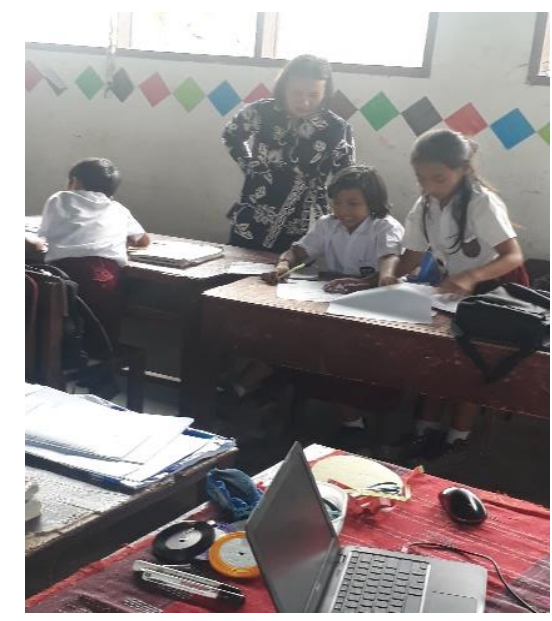

Gambar 3. Pendampingan Pembelajaran Konsep Pembagian Pecahan Menggunakan LAS

\section{3, 4 dan 5 (Tim Pengabdian oleh Ibu Juli Antasari Sinaga, S.Pd., M.Pd.)}

Kesulitan yang dialami ketika melaksanakan kegiatan ini adalah medan yang sulit dilalui dan jarak tempuh yang cukup jauh dari perkotaan. Untuk sampai ke lokasi tempat melaksanakan pengabdian harus melewati jalan setapak dan kebetulan pada saat itu kondisi cuaca sering hujan sehingga mengakibatkan jalanan berlumpur dan transportasi yang dapat digunakan hanya kendaraan sepeda motor. Kesulitan lainnya adalah perbedaan kemampuan siswa dalam memahami konsep mengakibatkan terjadinya penambahan waktu belajar sehingga mengganggu jam pelajaran berikutnya. Hal ini menjadi catatan penting bagi dosen dalam menentukan lamanya waktu kegiatan. Secara keseluruhan kegiatan ini terlaksana dengan baik dan rencana kedepan kegiatan pengabdian ini akan diteruskan kepada target sasaran siswa SMP.

\section{KESIMPULAN DAN SARAN}

Kegiatan pengabdian ini terlaksana dengan baik dan efektif dalam menuntaskan kesulitan siswa memahami konsep pembagian pecahan. Hal ini tercermin dari indikator keberhasilan siswa mencapai nilai tuntas diatas KKM sebesar $90 \%$ dan 100\% siswa memberikan respon positif atas proses pembelajaran dan $85 \%$ siswa menyatakan senang atas pembelajaran menggunakan media LAS yang didesain oleh tim dosen. Kegiatan seperti ini sangat membantu siswa dalam memahami konsep matematika, dan memotivasi belajar siswa. Oleh karena itu disarankan kepada pihak sekolah untuk tetap menjalin kerjasama dengan dosen-dosen di Program Studi Pendidikan Matematika FKIP Universitas HKBP Nommensen untuk menuntaskan berbagai kesulitan siswa dalam memahami konsep matematika. 
Desain Lembar Aktivitas Siswa (LAS) Untuk Meningkatkan Kemampuan Siswa Memahami Konsep Pembagian Pecahan SD Negeri 095173 Sihemun

Firman Pangaribuan, Juli Antasari Br. Sinaga, Herman

Volume 01, No. 01, April 2021 hal. 69-76

DOI Artikel : 10.46306/jub.v1i1.15

\section{DAFTAR PUSTAKA}

Ervin, H.K. (20I7). FRACTION MULTIPLICATION AND DIVISION MODELS: A PRACTITIONER REFERENCE PAPER. International Journal of Research in Education and Science (IJRES), 3(I), 258-279.

Friantini, R. N., Winata, R., Annurwanda, P., Suprihatiningsih, S., Annur, M. F., Ritawati, B. \& Iren. (2020). PENGUATAN KONSEP MATEMATIKA DASAR PADA ANAK USIA SEKOLAH DASAR. Jurnal Abdimas Bina Bangsa, I(2), 247-285.

Nizaruddin, Muhtarom, dan Nugraha, Aryan Eka Prastya. (2020). PELATIHAN PEMBUATAN MEDIA UNTUK JARAK JAUH. Jurnal Abdimas Bina Bangsa, I(I), 96-I06.

Pangaribuan, Firman. (2016). PROFIL ABSTRAKSI SISWA YANG BERGAYA KOGNITIF REFLEKTIF DAN SISWA YANG BERGAYA KOGNITIF IMPULSIF DALAM PEMBAGIAN PECAHAN. Disertasi. Semarang: Pascasarjana UNESA. 